\title{
IMPORTANCE OF WILD SPECIES KEPT IN CAPTIVITY AS \\ RESERVOIRS OF SALMONELLA SEROTYPES FOR HUMAN IN PETTING EXHIBITIONS AND ZOO IN IRAN WITH FOCUS ON ANTIMICROBIAL RESISTANCE
}

\author{
Hamid Staji ${ }^{1}$, Ladan Zandiar $^{2}$ \\ ${ }^{1}$ Department of Pathobiology, Faculty of Veterinary Medicine, \\ Semnan University, Semnan, Iran \\ ${ }^{2}$ Veterinary Medicine Laboratory Student, Semnan University, Semnan, Iran
}

Received 28 May 2017; Received in revised form 5 August 2017; Accepted 24 August 2017

\begin{abstract}
Salmonella spp. is the leading cause of zoonotic enteric diseases wich represents a public health concern worldwide. The incidence of zoo-associated salmonellosis is rather high due to the high prevalence and shedding of this bacterium from wild animals specially kept in stressful conditions. To determine the potential public health risk presented by zoo animals in Semnan, we investigated the prevalence of Salmonella serovars Enteritidis and Typhimurium among wild animal species kept in the zoo and pet shops. Totally, 152 fecal samples from species in the zoo and pet shops were collected and Salmonella prevalence and identification was assessed via standard bacteriologic culture methods, serotyping, multiplexPCR and antimicrobial susceptibility testing. Overall, 21\% (32/152) of the samples were confirmed positive for Salmonella and serotyping showed 12.5\% (19/32) Salmonella serovar Enteritidis and 8.5\% (13/32) serovar Typhimurium, respectively. All the Salmonella isolates were sensitive to Chloramphenicole, Flurefenicole, Meropenem, Ceftizoxime, Imipenem and Ampicillin, while resistance was observed in the case of Nalidixic acid (78\%) as the highest resistance, Streptomycin (28\%), Oxytetracycline, Neomycin, Furazolidone (each one 15\%) and Lincospectin (9.3\%). The high occurrence of multidrug resistance Salmonella in zoo and pet animals represents a potential threat to public health and requires strict surveillance and application of hygienic criteria.
\end{abstract}

Key words: Salmonella, wild species in captivity, serotyping, multiplex-PCR, antimicrobial resistance

\section{INTRODUCTION}

Salmonella is an enteric, facultative intracellular and ubiquitous pathogen with a high zoonotic potential (1). The species Salmonella enterica is the most important pathogen of the genus and includes six subspecies: enterica, indica, houtenae, salamae, arizonae, diarizonae. The subsp. enterica is usually

\footnotetext{
Corresponding author: Prof. Hamid Staji, $\mathrm{PhD}$

E-mail address: hstaji@semnan.ac.ir

Present address: Department of Pathobiology, Faculty of Veterinary

Medicine, Semnan University, p. code: 35131-1911, Semnan, Iran

Phone: +98 2331533614 Fax: 982333654214

Copyright: (C) 2017 Staji H. This is an open-access article published under the terms of the Creative Commons Attribution License which permits unrestricted use, distribution, and reproduction in any medium, provided the original author and source are credited.

Competing Interests: The authors have declared that no competing interests exist.

Available Online First: 9 September 2017

Published on: 15 October 2017

https://doi.org/10.1515/macvetrev-2017-0025
}

implicated in warm-blooded host's infections with major zoonotic importance $(2,3)$. Infections due to Salmonella may be asymptomatic or may persist through gastrointestinal infections to potentially fatal systemic disease. In the United States as a developed country with very high hygienic surveillance, there are an estimated 1.0 million annual cases of human nontyphoidal salmonellosis with approximately estimated 380 annual deaths and 19,000 estimated annual hospitalizations, while in other regions these figures may be higher due to poor hygienic criteria (4). The death toll is much higher in third-world countries, where typhoid fever is a major killer due to poor sanitary conditions. In Iran, there are thousands of reported cases annually of foodborne diseases related to Salmonella $(5,6)$. This infectious agent is transmitted from animal reservoirs to humans mainly via contaminated 
foods, direct/indirect contact with infected hosts or environment.Today, zoonosis with livestock or captured wild life reservoirs constitutes a superior public health problem (7-9).

There are several documents indicating that the prevalence of Salmonella in captured wildlife as well captured species in zoos and petting exhibitions has increased significantly in recent years. Various factors including stress because of food shortage, poor husbandry with overcrowding and the introduction of new hosts may cause the distribution of Salmonella serovars in the environment and the increase in new reservoirs for humans (10-13). Thereare no documented investigations about antimicrobial resistance of Non-Typhoidal salmonella (NTS) strains circulating in wildlife kept in zoo in the Semnan province, but some information is available regarding Salmonella infection and their antimicrobial resistance profile (versus different antibiotics) from wild captive animals in other regions of Iran. For example, in a study carried out within free living sparrows in Tehran suburbs, all the Salmonella isolates were sensitive to Norfloxacin, Flumequine, Ampicillin, and Sultrim, and 35\% were resistant to Lincospectin (3). In another study regarding the antimicrobial resistance profile of Salmonella strains from birds in parks and pet shops in Tehran, all isolates were susceptible to Danofloxacin, Norfloxacin, Levofloxacin, Amikacin, Gentamicin, and Tobramycin. Resistance to other antibacterial agents was variable and ranged from 0-57.9\% (12). Also, a similar study in the Mashhad zoo (Khorasan-e-Razavi, East of Iran) regarding salmonella antimicrobial resistance phenotypes from wild captive herbivores showed the highest rate of resistance against Amoxicillin (100\%), Tetracycline (80\%), Neomycin (60\%), Lincospectin $(50 \%)$ and Enrofloxacin (40\%), while resistance to Furazolidone wasn't observed (14). Another report about resistance to Fluoroquinolones within nontyphoidal Salmonella serovars from human cases showed a $6.3 \%$ resistance rate (15).

The aim of the present study was to evaluate the prevalence of Salmonella enterica serovars Typhimurium and Enteritidis, the two major serovars implicated in human salmonellosis, within wild birds and mammals kept in captivity in the Semnan zoo and pet shops in Semnan City using biochemical and genotypic assays. Furthermore, we provide the assessment of antimicrobial resistance phenotype of the isolated Salmonella strains.

\section{MATERIAL AND METHODS}

\author{
Sample collection, isolation of Salmonella \\ strains and serotyping
}

This is a cross-sectional study carried out in the period from winter to April of 2015-2016 in Semnan City, Semnan Province (north-east of Iran). In total, 152 fecal samples were collected from animals which were healthy (except for two monkeys that were both suffering from diarrhea), clinically. All animals were adult, kept in fences/cages separate from other species without direct contact to visitors in the zoo and the pet shops. The host species and the number of samples from each species (including mammals and birds) were as follows (Taxonomic Name/English Name(No. of animals testes): Macaca mulatta/Rhesus macaque (2); Aquila pomarinal Lesser spotted eagle (10); Tyto alba/Bran owl (2); Equus ferus caballus/Horse (4); Ursus arctos/ Brown Bear (2); Capra aegagrus hircus/Wild Goat (5); Psittacula krameri/Ring-necked parakeet (15); Numida meleagris/Guineafowl (5); Canis lupus/ Wolf (15); Dama dama mesopotamica/Persian fallow deer (1); Oryctolagus Cuniculus/Rabbit (4); Pavo muticus/Green peafowl (4); Carduelis carduelis/Goldfinch (10); Taeniopygia guttatal Zebra finch (10); Serinus canaria/Canary (6); Psittacus erithacus/Congo African grey parrot (4); Acridotheres tristis/Common Myna (8); Phasianus colchicus/Common pheasant (15) and Columba livia/Pigeon (30). Faecal samples were placed on ice and transported immediately to the microbiology laboratory (Faculty of Veterinary Medicine, Semnan University), and Salmonella strains were isolated using standard (Culturing \& Biochemical) methods as described by Mirzaei et al. (3). All isolated Salmonella strains were then serotyped using Salmonella H Antisera and Salmonella O Antisera (Difco). Briefly, the Salmonella isolates were cultured onto TSI slant medium and grown overnight at $37{ }^{\circ} \mathrm{C}$, and afterward the isolates were serotyped using antisera $\mathrm{O}(\mathrm{B}, \mathrm{D}, \mathrm{E}, \mathrm{C})$ and $\mathrm{H}$, respectively to determine the serogroups and serotypes of the isolates $(6,7)$.

\section{$D N A$ extraction and multiplex-PCR}

Genomic DNA was extracted from Salmonella isolates with the Rapid One-Step Extraction (ROSE) method (16). Then, Multiplex PCR was conducted with 2 independent sets for genetic identification of Salmonella serovar Typhimurium (targeting invA, rfbJ, fliC and $f l j B$ ) and Salmonella serovar Enteritidis (targeting $s p v$ and $s e f A$ ) (primers 
sequences present in Table 1). For Salmonella ser. Typhimurium, PCR was performed in a 25 $\mu \mathrm{L}$ volume containing $40 \mathrm{ng}$ of total Salmonella ser. Typhimurium extracted DNA, $8 \mu \mathrm{L}$ of each primer and $13 \mu \mathrm{L}$ of $2 \mathrm{X}-\mathrm{PCR}$ master mix (Jena, Takapouzist). Thermal and electrophoresis conditions were as previously described by Zahraei Salehi et al. (17). For Salmonella ser. Enteritidis, PCR was performed in a total volume of $25 \mu \mathrm{L}$ amplification mixture consisting of $15 \mu \mathrm{L}$ of $2 \mathrm{X}$ mentioned Master mix, $1 \mu \mathrm{L}$ of each primer and 3 $\mu \mathrm{L}$ of DNA (40 ng) that was extracted as template using thermal and gel electrophoresis condition described by Pan and Liu (18). distribution of antimicrobial resistance versus two diagnosed serotypes (Enteritidis and Typhimurium) were analyzed using Chi-Square (X2) and Fisher's Exact Test at $95 \%$ of confidence and $\mathrm{P}=0.05$ of significant level.

\section{RESULTS}

Fecal samples were collected from 152 animals (115 birds and 37 mammals), and Salmonella spp. strains were found in $27(23.4 \%)$ and 5 (13.5\%) of these animals, respectively.

In total, thirty two Salmonella strains were

Table 1. Primers used for the genetic characterization of Salmonella serovars Typhimurium and Enteritidis

\begin{tabular}{|c|c|c|c|c|c|}
\hline $\begin{array}{l}\text { Salmonella } \\
\text { enterica } \\
\text { Serotype }\end{array}$ & Primer & Target Gene & Sequence $\left(5^{\prime}-3^{\prime}\right)$ & $\begin{array}{l}\text { Product } \\
\text { Size (bp) }\end{array}$ & Reference \\
\hline \multirow{8}{*}{$\begin{array}{c}\text { Serovar } \\
\text { Typhimurium }\end{array}$} & ST139-s & \multirow[b]{2}{*}{ invA } & GTGAAATTATCGCCACGTTCGGGCAA & & \multirow{8}{*}{$\begin{array}{c}\text { Zahraei Salehi et } \\
\text { al. (17) }\end{array}$} \\
\hline & $\begin{array}{l}\text { ST141- } \\
\text { as }\end{array}$ & & TCATCGCACCGTCAAAGGAACC & 284 & \\
\hline & Rfbj-s & \multirow{2}{*}{$r f b J$} & CCAGCACCAGTTCCAACTTGATAC & & \\
\hline & Rfbj-as & & GGCTTCCGGCTTTATTGGTAAGCA & 663 & \\
\hline & Flic-s & \multirow{2}{*}{$\mathrm{fliC}$} & ATAGCCATCTTACCAGTTCCCCC & & \\
\hline & Flic-as & & GCTGCAACTGTTACAGGATATGCC & 183 & \\
\hline & Fljb-s & \multirow{2}{*}{$f j B$} & ACGAATGGTACGGCTTCTGTAACC & & \\
\hline & Fljb-as & & TACCGTCGATAGTAACGACTTCGG & 526 & \\
\hline \multirow{5}{*}{$\begin{array}{c}\text { Serovar } \\
\text { Enteritidis }\end{array}$} & & Target Gene & Sequence $\left(5^{\prime}-3^{\prime}\right)$ & $\begin{array}{l}\text { Product } \\
\text { Size (bp) }\end{array}$ & \multirow{5}{*}{ Pan and Liu (18) } \\
\hline & S1 & \multirow{2}{*}{$S p v^{*}$} & GCCGTACACGAGCTTATAGA & & \\
\hline & S4 & & ACCTACAGGGGCACAATAAC & 250 & \\
\hline & SEFA2 & \multirow{2}{*}{$\operatorname{sef} A^{* *}$} & GCAGCGGTTACTATTGCAGC & & \\
\hline & SEFA4 & & TGTGACAGGGACATTTAGCG & 310 & \\
\hline $\begin{array}{l}\text { * Salmonella pla } \\
\text { * S. ser. Enterit }\end{array}$ & $\begin{array}{l}\text { I virule } \\
\text { imbrial }\end{array}$ & $\begin{array}{l}\text { e } \\
\text { en gene }\end{array}$ & & & \\
\hline
\end{tabular}

\section{Antimicrobial susceptibility testing}

Antimicrobial susceptibility of confirmed Salmonella isolates was determined by the disk diffusion method according to the guidelines provided by the Clinical and Laboratory Standards Institute (CLSI) (19) and twelve antibiotic disks were applied to identify the antimicrobial resistance phenotype of the isolated strains as follow: Ampicillin; Ceftizoxime; Oxytetracycline; Streptomycin, Lincospectin, Neomycin; Imipenem, Meropenem; Nalidixic acid; Furazolidone; Flurefenicole and Chloramphenicole. Finally, isolated from $152(21 \%)$ fecal droplets of various animals kept in captivity consisting of 19 (12.5\%) Salmonella serovar Enteritidis (all strains were isolated from bird's species) and 13 (8.5\%) serovar Typhimurium (5.2\% isolates from birds, $2 \%$ from mammals and $1.3 \%$ from rodents, respectively). Distribution of Salmonella serovars within monitored animals, including the number of isolates from each host, are presented in Table 2. The results of Multiplex-PCR gel electrophoresis for genetic confirmation of Salmonella serovars are present in Figure 1. 


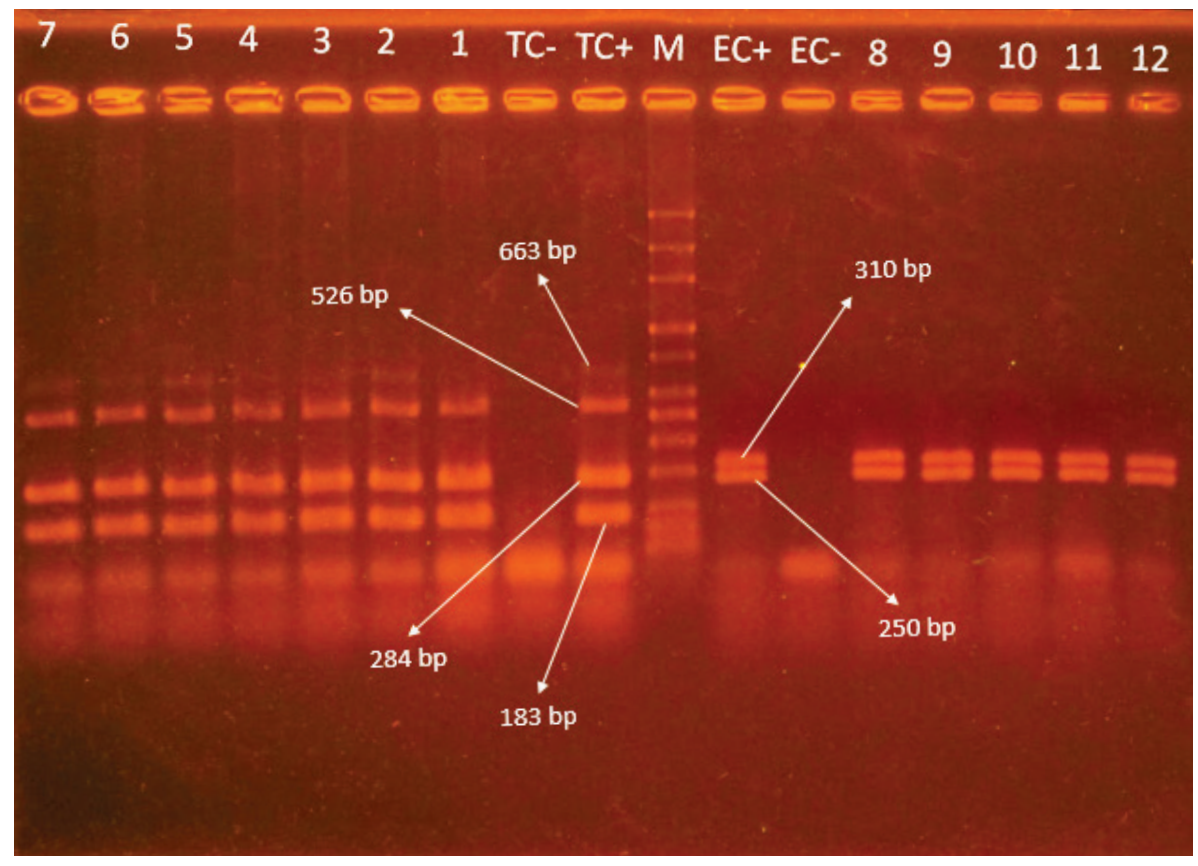

Figure 1. Gel electrophoresis of Multiplex-PCR for detection of $S$. serovars Typhimurium \& Enteritidis. Lane M: 50 bp marker. Lanes TC- \& EC-: negative controls for Typhimurium and Enteritidis, respectively. Lanes TC+ \& EC+: positive controls for Typhimurium and Enteritidis serovars, respectively. Lanes 1-7: Typhimurium isolates. Lane 8-12: Enteritidis isolates

The overall majority of the Salmonella isolates (93.7\%) showed resistance to at least one of the antibiotics tested except for two Salmonella serovar Typhimurium strains $(6.3 \%)$, which were sensitive to all antimicrobials. Antimicrobial resistance was observed for six antibiotics including Nalidixic acid $(78 \%)$ as the highest resistance, then Streptomycin (28\%), Oxytetracycline, Neomycin, Furazolidone (each 15\%) and Lincospectin (9.3\%), respectively and all isolates showed sensitivity to Chloramphenicole, Flurefenicole, Meropenem, Ceftizoxime, Imipenem and Ampicillin antibiotics. The distribution of antimicrobial resistance patterns within all isolates, $S$. ser. Enteritidis and $S$. ser. Typhimurium are summarized and presented in Table 2.

Statistical analysis of the results revealed that there is no significant difference in distribution of antimicrobial resistance patterns between the two isolated serotypes. Statistical analysis between isolates of serovars Typhimurium and Enteritidis showed that the resistance to only one antimicrobial in Enteritidis strains are higher than Typhimurium ones $(p=0.014)$, significantly. There was no significant difference between isolates belonging to both serotypes from a Multidrug-Resistance
(Resistance to more than two antibiotics) point of view.

\section{DISCUSSION}

Salmonella presence and isolation from captured wild animals has been reported from all over the world and human infection by exoticassociated salmonellosis has been increasing throughout the world because more people are in contact with exotic species not only indoors, but also at zoos and petting exhibitions. (20-24). Although infection of humans with salmonella serovars in zoos is not common, there is some published data demonstrating the outbreaks of non-typhoid Salmonellosis in zoo visitors. For example Friedman et al. (25) reported an outbreak of Salmonellosis in 39 children visiting a reptile exhibition in Denver, Colorado (25) or since 1966 until now, there are several other published zoonotic disease outbreaks associated with animal exhibits $(24,26,27)$. Therefore, zoo visitors and zookeepers are at risk of infection from animal carriers. The aim of this study was to ascertain the prevalence of Salmonella serovars Enteritidis and 
Table 2. Distribution of antibiotic resistance patterns in Salmonella serovars Typhimurium and Enteritidis isolates in this study with the source of isolation using Disk Diffusion method

\section{Antibiotic Disk's}

\begin{tabular}{|c|c|c|c|c|c|c|c|c|c|c|c|c|c|c|}
\hline $\begin{array}{l}\text { Salmonella } \\
\text { enterica } \\
\text { serovars }\end{array}$ & Host species & $\begin{array}{l}\text { No. of } \\
\text { isolates }\end{array}$ & $\mathbf{F}$ & AMP & ST & $\begin{array}{l}\text { LIN- } \\
\text { SP }\end{array}$ & IMI & NA & $\mathrm{CZ}$ & MER & OXY & NEO & FLU & CHL \\
\hline \multirow{13}{*}{ 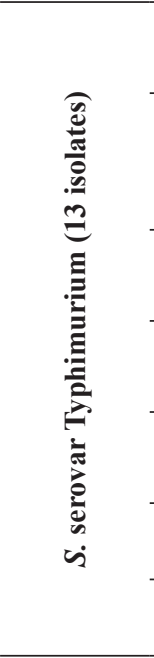 } & \multirow{2}{*}{$\begin{array}{l}\text { Macaca } \\
\text { mulatta }\end{array}$} & \multirow{2}{*}{2} & $S$ & $S$ & SR & $S$ & $S$ & $\mathrm{R}$ & $S$ & $S$ & $\mathrm{~S}$ & SR & $S$ & $\mathrm{~S}$ \\
\hline & & & SR & $\mathrm{S}$ & SR & $\mathrm{S}$ & $\mathrm{S}$ & $\mathrm{R}$ & $\mathrm{S}$ & $\mathrm{S}$ & $\mathrm{S}$ & SR & $\mathrm{S}$ & $\mathrm{S}$ \\
\hline & \multirow{3}{*}{$\begin{array}{c}\text { Acridotheres } \\
\text { tristis }\end{array}$} & \multirow{3}{*}{3} & $\mathrm{R}$ & $\mathrm{S}$ & $\mathrm{R}$ & $\mathrm{R}$ & $\mathrm{S}$ & $\mathrm{R}$ & $\mathrm{S}$ & $S$ & $\mathrm{R}$ & $\mathrm{R}$ & $\mathrm{S}$ & $\mathrm{S}$ \\
\hline & & & $\mathrm{S}$ & $\mathrm{S}$ & SR & $\mathrm{S}$ & $\mathrm{S}$ & $\mathrm{S}$ & $\mathrm{S}$ & $\mathrm{S}$ & $\mathrm{S}$ & $\mathrm{S}$ & $S$ & $\mathrm{~S}$ \\
\hline & & & $\mathrm{S}$ & $\mathrm{S}$ & SR & $\mathrm{S}$ & $\mathrm{S}$ & $\mathrm{R}$ & $\mathrm{S}$ & $S$ & $\mathrm{~S}$ & $\mathrm{R}$ & $S$ & $\mathrm{~S}$ \\
\hline & \multirow{2}{*}{$\begin{array}{l}\text { Columba } \\
\text { livia }\end{array}$} & \multirow{2}{*}{2} & $\mathrm{~S}$ & $\mathrm{~S}$ & $\mathrm{R}$ & $\mathrm{S}$ & $\mathrm{S}$ & $\mathrm{S}$ & $\mathrm{S}$ & $\mathrm{S}$ & $\mathrm{S}$ & $\mathrm{S}$ & $\mathrm{S}$ & $\mathrm{S}$ \\
\hline & & & $\mathrm{S}$ & $\mathrm{S}$ & $\mathrm{R}$ & $\mathrm{S}$ & $\mathrm{S}$ & $\mathrm{S}$ & $\mathrm{S}$ & $\mathrm{S}$ & $\mathrm{S}$ & SR & $\mathrm{S}$ & $\mathrm{S}$ \\
\hline & \multirow{2}{*}{$\begin{array}{c}\text { Oryctolagus } \\
\text { Cuniculus }\end{array}$} & \multirow{2}{*}{2} & $\mathrm{R}$ & $\mathrm{S}$ & $\mathrm{R}$ & SR & $\mathrm{S}$ & $\mathrm{R}$ & $\mathrm{S}$ & $\mathrm{S}$ & $\mathrm{R}$ & $\mathrm{S}$ & $\mathrm{S}$ & $\mathrm{S}$ \\
\hline & & & SR & $\mathrm{S}$ & $\mathrm{S}$ & $\mathrm{S}$ & $\mathrm{S}$ & $\mathrm{R}$ & $\mathrm{S}$ & $\mathrm{S}$ & $\mathrm{S}$ & SR & $\mathrm{S}$ & $\mathrm{S}$ \\
\hline & \multirow{2}{*}{$\begin{array}{c}\text { Aquila } \\
\text { pomarina }\end{array}$} & \multirow{2}{*}{2} & $\mathrm{R}$ & $\mathrm{S}$ & $\mathrm{R}$ & $\mathrm{R}$ & $\mathrm{S}$ & $\mathrm{R}$ & $\mathrm{S}$ & $\mathrm{S}$ & $\mathrm{R}$ & $\mathrm{R}$ & $\mathrm{S}$ & $\mathrm{S}$ \\
\hline & & & $\mathrm{S}$ & $\mathrm{S}$ & SR & $\mathrm{S}$ & $\mathrm{S}$ & $\mathrm{S}$ & $\mathrm{S}$ & $\mathrm{S}$ & $\mathrm{S}$ & $\mathrm{S}$ & $\mathrm{S}$ & $\mathrm{S}$ \\
\hline & $\begin{array}{c}\text { Equus ferus } \\
\text { caballus }\end{array}$ & 1 & $\mathrm{R}$ & S & $\mathrm{R}$ & SR & S & $\mathrm{R}$ & S & S & $\mathrm{R}$ & $\mathrm{S}$ & $\mathrm{S}$ & $\mathrm{S}$ \\
\hline & $\begin{array}{c}\text { Taeniopygia } \\
\text { guttata }\end{array}$ & 1 & S & S & SR & S & S & $\mathrm{R}$ & $\mathrm{S}$ & S & $\mathrm{S}$ & SR & $\mathrm{S}$ & $\mathrm{S}$ \\
\hline \multicolumn{3}{|c|}{$\begin{array}{l}\text { Total no. of resistant isolates } \\
\text { to each antibiotic in serovar } \\
\text { Typhimurium }(\%)\end{array}$} & $\begin{array}{c}4 \\
(30.7)\end{array}$ & 0 & $6(46)$ & $\begin{array}{c}2 \\
(15.4)\end{array}$ & 0 & $\begin{array}{c}9 \\
(69)\end{array}$ & 0 & 0 & $\begin{array}{c}4 \\
(30.7)\end{array}$ & $3(23)$ & 0 & 0 \\
\hline \multirow{19}{*}{ 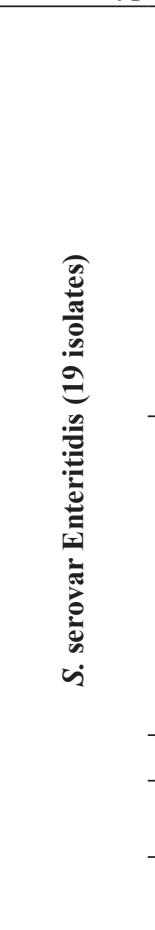 } & \multirow{9}{*}{$\begin{array}{l}\text { Phasianus } \\
\text { colchicus }\end{array}$} & \multirow{9}{*}{9} & $S$ & $\mathrm{~S}$ & $S$ & $S$ & $S$ & $\mathrm{R}$ & $S$ & $\mathrm{~S}$ & $\mathrm{~S}$ & SR & $S$ & $S$ \\
\hline & & & $\mathrm{S}$ & $\mathrm{S}$ & SR & $\mathrm{S}$ & $S$ & $\mathrm{R}$ & $S$ & $S$ & $\mathrm{~S}$ & SR & $S$ & $S$ \\
\hline & & & SR & $\mathrm{S}$ & $\mathrm{S}$ & $\mathrm{S}$ & $\mathrm{S}$ & $\mathrm{R}$ & $\mathrm{S}$ & $\mathrm{S}$ & $\mathrm{S}$ & SR & $\mathrm{S}$ & $\mathrm{S}$ \\
\hline & & & SR & $S$ & SR & $S$ & $S$ & $\mathrm{R}$ & $S$ & $S$ & $\mathrm{~S}$ & SR & $\mathrm{S}$ & $\mathrm{S}$ \\
\hline & & & SR & $\mathrm{S}$ & $\mathrm{S}$ & $\mathrm{S}$ & $\mathrm{S}$ & $\mathrm{R}$ & $\mathrm{S}$ & $S$ & $\mathrm{~S}$ & $\mathrm{~S}$ & $\mathrm{~S}$ & $\mathrm{~S}$ \\
\hline & & & $\mathrm{S}$ & SR & SR & $\mathrm{S}$ & $\mathrm{S}$ & $\mathrm{R}$ & $\mathrm{S}$ & $\mathrm{S}$ & SR & SR & $\mathrm{S}$ & $\mathrm{S}$ \\
\hline & & & $\mathrm{S}$ & $\mathrm{S}$ & SR & $\mathrm{S}$ & $\mathrm{S}$ & $\mathrm{R}$ & $\mathrm{S}$ & $\mathrm{S}$ & $\mathrm{S}$ & $\mathrm{R}$ & $\mathrm{S}$ & $\mathrm{S}$ \\
\hline & & & $\mathrm{S}$ & $\mathrm{S}$ & $\mathrm{S}$ & $\mathrm{S}$ & $\mathrm{S}$ & $\mathrm{R}$ & $\mathrm{S}$ & $\mathrm{S}$ & $\mathrm{S}$ & $\mathrm{S}$ & $\mathrm{S}$ & $\mathrm{S}$ \\
\hline & & & $S$ & $S$ & SR & $\mathrm{R}$ & $S$ & $\mathrm{~S}$ & $S$ & $S$ & $\mathrm{~S}$ & $\mathrm{~S}$ & $\mathrm{~S}$ & $S$ \\
\hline & \multirow{7}{*}{$\begin{array}{l}\text { Columba } \\
\text { livia }\end{array}$} & \multirow{7}{*}{7} & $\mathrm{~S}$ & $\mathrm{~S}$ & $\mathrm{R}$ & $\mathrm{S}$ & $\mathrm{S}$ & $\mathrm{S}$ & $\mathrm{S}$ & $\mathrm{S}$ & $\mathrm{S}$ & $\mathrm{S}$ & $\mathrm{S}$ & $\mathrm{S}$ \\
\hline & & & $\mathrm{S}$ & $\mathrm{S}$ & $\mathrm{R}$ & $\mathrm{S}$ & $\mathrm{S}$ & $\mathrm{S}$ & $\mathrm{S}$ & $\mathrm{S}$ & $\mathrm{S}$ & SR & $\mathrm{S}$ & $\mathrm{S}$ \\
\hline & & & $\mathrm{R}$ & $\mathrm{S}$ & $\mathrm{R}$ & SR & $\mathrm{S}$ & $\mathrm{R}$ & $\mathrm{S}$ & $\mathrm{S}$ & $\mathrm{R}$ & $\mathrm{S}$ & $\mathrm{S}$ & $\mathrm{S}$ \\
\hline & & & SR & $\mathrm{S}$ & SR & $\mathrm{S}$ & $\mathrm{S}$ & $\mathrm{R}$ & $S$ & $S$ & $\mathrm{~S}$ & SR & $\mathrm{S}$ & $\mathrm{S}$ \\
\hline & & & SR & $\mathrm{S}$ & $\mathrm{S}$ & $\mathrm{S}$ & $\mathrm{S}$ & $\mathrm{R}$ & $\mathrm{S}$ & $\mathrm{S}$ & $\mathrm{S}$ & $\mathrm{S}$ & $\mathrm{S}$ & $\mathrm{S}$ \\
\hline & & & $\mathrm{S}$ & $\mathrm{S}$ & SR & $\mathrm{S}$ & $\mathrm{S}$ & $\mathrm{R}$ & $\mathrm{S}$ & $\mathrm{S}$ & $\mathrm{S}$ & SR & $\mathrm{S}$ & $\mathrm{S}$ \\
\hline & & & SR & $\mathrm{S}$ & $\mathrm{S}$ & $\mathrm{S}$ & $\mathrm{S}$ & $\mathrm{R}$ & $S$ & $\mathrm{~S}$ & $\mathrm{~S}$ & SR & S & $\mathrm{S}$ \\
\hline & Anser anser & 1 & $\mathrm{~S}$ & SR & SR & $\mathrm{S}$ & $\mathrm{S}$ & $\mathrm{R}$ & $\mathrm{S}$ & $\mathrm{S}$ & SR & SR & $\mathrm{S}$ & $\mathrm{S}$ \\
\hline & $\begin{array}{l}\text { Serinus } \\
\text { canaria }\end{array}$ & 1 & $\mathrm{~S}$ & $\mathrm{~S}$ & SR & $\mathrm{S}$ & S & $\mathrm{R}$ & $\mathrm{S}$ & S & $\mathrm{S}$ & $\mathrm{R}$ & S & $\mathrm{S}$ \\
\hline & $\begin{array}{l}\text { Carduelis } \\
\text { carduelis }\end{array}$ & 1 & S & S & S & $\mathrm{S}$ & S & $\mathrm{R}$ & S & S & S & S & $\mathrm{S}$ & S \\
\hline \multicolumn{3}{|c|}{$\begin{array}{c}\text { Total no. of resistant isolates } \\
\text { to each antibiotic in serovar } \\
\text { Enteritidis (\%) }\end{array}$} & $1(5)$ & 0 & $\begin{array}{c}3 \\
(15.7)\end{array}$ & $1(5)$ & 0 & $\begin{array}{c}16 \\
(84)\end{array}$ & 0 & 0 & $1(5)$ & $2(10)$ & 0 & 0 \\
\hline \multicolumn{3}{|c|}{$\begin{array}{c}\text { Total no. of resistant isolates to } \\
\text { each antibiotic in both serovars } \\
(\%)\end{array}$} & $5(15)$ & 0 & $9(28)$ & $\begin{array}{c}3 \\
(9.3)\end{array}$ & 0 & $\begin{array}{c}25 \\
(78)\end{array}$ & 0 & 0 & $5(15)$ & $5(15)$ & 0 & 0 \\
\hline
\end{tabular}

$*_{\mathrm{R}}=$ Resistant; $\mathrm{S}=$ sensitive; SR = Semi-Resistant. F: Furazolidone; AMP: Ampicillin; ST: Streptomycin; LIN-SP: Lincospectin; IMI: Imipenem; NA: Nalidixic acid; CZ: Ceftizoxime; MER: Meropenem; OXY: Oxytetracycline; NEO: Neomycin; FLU: Flurefenicole; CHL: Chloramphenicole 
Typhimurium in zoo animals at Semnan Zoo and some pet shops in Iran.

Salmonella serotypes belonging to subspecies I are responsible for more than $99 \%$ of Salmonella infections in humans. This is because generally, these members are found in warm blooded hosts and to a lesser extent in cold blooded animals like reptiles, whereas other subspecies are isolated from cold-blooded vertebrates and their environments. All 32 Salmonella isolates in our study belonged to subspecies I (59.3\% Salmonella ser. Enteritidis and $40.6 \%$ Typhimurium) and according to the Centers for Disease Control and Prevention (CDC), Salmonella serovars Typhimurium and Enteritidis are the two most common serovars associated with human disease, therefore, occurrence of these strains in zoo and pet species in Semnan represents a potential threat to public health $(4,28)$. In some developed countries like the United States and in other areas of the world, Salmonella serovar Typhimurium is the second most commonly reported serotype causing salmonellosis in humans and the major cause of salmonellosis in wild birds with high mortality among infected birds (2931). This data suggest the high importance of this serotype in animals mortality kept in captivity in Semnan, especially birds. Furthermore, the serovar Typhimurium has been the most common reported serotype distinguished in other non-human hosts, underscoring the wide host range and complex ecology of this serotype (23). This fact can explain better the prevalence of Typhimurium serovar in exotic species other than birds in the Semnan zoo and pet shops. In the present study, Salmonella serovar Enteritidis was identified as the most prevalent serovar within avian species and this is in parallel with other studies in Iran where the prevalence of Salmonella serovars within domestic/wild and pet birds has been demonstrated $(3,12,32)$. Keeping multiple birds in close contact with each other and in contact to other non-bird species provides the ideal environment for infectious agents to spread easily with susceptible hosts. This explains why serovar Typhimurium was another prevalent agent in our study in bird species. In common with this, wildlife can be infected with Salmonella serovars before capturing via contact to livestock or other wild reservoirs. The high prevalence of such serovars within zoo and animal exhibitions can be due to rodents or free living birds like sparrows circulating within species cages/area, as well as the close and intense contact between them (3).

There has been a serious increase in resistance of Salmonella serovars to antibiotics over the last years and territorial variations of resistance to antibiotics may be explained in part by different regional antimicrobial administrations (33, 34). Antimicrobial resistance phenotypes of Salmonella isolates obtained in the present study showed resistance to Nalidixic acid (78\%), Streptomycin (28\%), Oxytetracycline, Neomycin, Furazolidone (each 15\%) and Lincospectin (9.3\%), respectively and all isolates showed sensitivity to Chloramphenicole, Flurefenicole, Meropenem, Ceftizoxime, Imipenem and Ampicillin antibiotics. Today, some antimicrobials are not used any more in human practice, such as Furazolidone and Chloramphenicol, but some are still in use in animal husbandry like Oxytetracycline, Lincospectin and Flurefenicole. The presence of resistance to Oxytetracycline, Furazolidone and Lincospectin may indicate the livestock as the source of Salmonella strains for wild animal species in nature or in a zoo environment. There are several documents showing the interactions of infectious agents between farm animals and wildlife. Circulation of such agents within these two sources and distribution of antimicrobial agents between these agents $(8,27,35,36)$ (e.g. feeding animals with infected foods with animal origin) may explain the probable way for the presence of such antimicrobial resistances in zoo species. In the present study, the prevalence of resistance to Nalidixic acid, Streptomycin and Neomycin as the antimicrobials still in use for the treatment of human infections, is another health problem.

These results show the risk of Salmonella strains to transmit these antimicrobial resistance traits to human populations. Also, from another point of view, these results show the possible role of humans as the source of salmonella infections for pet animals, because some investigations have revealed human cases as the source of this infectious agent for animals (37-39). Salmonella serovars may be passed in animal feces and transmitted to humans through fecal-oral contact due to poor hygienic practices, attraction to or curiosity about animals like petting and wild species kept in zoos. Usually, infants and children are at the greatest risk of acquiring zoonotic pathogens from animals (4042). In many cases, the transmission of zoonotic agents and antimicrobial resistance from nonhuman species to humans are preventable through improved hygiene and surveillance by strict monitoring programs in petting exhibitions and zoo environment. 


\section{CONCLUSION}

In conclusion, our results demonstrated a high prevalence of Salmonella serovars Enteritidis \& Typhimurium in wild animals living in captivity in Semnan City. Furthermore, resistance to different antibiotics (used in human medicine and veterinary medicine) may represent a different route of infection for the mentioned wild animals. These animals can play an important role in the dissemination and transmission of these resistant serovars into the environment and to other hosts such as livestock and humans via direct/indirect contact.

\section{CONFLICT OF INTEREST STATEMENT}

The authors declared that they have no potential conflict of interest with respect to the authorship and/or publication of this article.

\section{ACKNOWLEDGMENT}

Authors express their willing's to the Head of Faculty of Veterinary Medicine, Semnan University for providing facilities for the present study and Mrs. S. Birgani Farhani and Mrs. Behnaz Raeisian for their cooperation's in laboratory experiments.

\section{REFERENCES}

1. Pan, Z. M., Geng, S. Z., Zhou, Y. Q., Liu, Z. Y., Fang, Q., Liu, B. B., Jiao, X. A. (2010). Prevalence and antimicrobial resistance of Salmonella spp. isolated from domestic animals in Eastern China. J Anim Vet Adv. 9 (17): 2290-2294.

https://doi.org/10.3923/javaa.2010.2290.2294

2. Herrera-León, S., Ramiro, R., Arroyo, M., Díez, R., Usera, M. A., Echeita, M. A. (2007). Blind comparison of traditional serotyping with three multiplex PCRs for the identification of Salmonella serotypes. Res Microbil. 158 (2): 122-127.

https://doi.org/10.1016/j.resmic.2006.09.009 PMid:17258433

3. Mirzaie, S., Hassanzadeh, M., Ashrafi, I. (2010). Identification and characterization of Salmonella isolates from captured house sparrows. Turk J Vet Anim Sci. 34 (2): 181-186.
4. Centers for Disease Control and Prevention (CDC): Salmonella: Salmonella infection. https://www.cdc.gov/salmonella/index.html

5. Dallal, M. M. S. (2014). Prevalence of Salmonella spp. in packed and unpacked red meat and chicken in south of Tehran. Jundishapur J Microbiol. 7 (4): e9254. PMCID: PMC4138620

6. Staji, H., Tonelli, A., Zahraei Salehi, T., Iorio, M., Lopes, F. (2015). Genetic Characterization of Salmonella Typhimurium isolates from faeces of children with gastroenteritis hospitalized in Baqiatollah-Azam Hospital, Tehran, Iran. J Med Microbiol Infect Dis. 3(1): 32-39.

7. Staji, H., Rezaei, S., Rassouli, M., Namroodi, S. (2016). Prevalence and genetic characteristics of Salmonella strains in wild mallard ducks (Anas plathyrhincus) in Semnan suburb, Iran. Bulg J Vet Med. Online First: http://tru.uni-sz.bg/bjvm/H.\%20 Staji\%20OnFirst.pdf

8. Krawiec, M., Kuczkowski, M., Kruszewicz, A. G., Wieliczko, A. (2015). Prevalence and genetic characteristics of Salmonella in free-living birds in Poland. BMC Vet Res. 11 (1): 2-8.

https://doi.org/10.1186/s12917-015-0332-x PMid:25636375 PMCid:PMC4316766

9. Jamshidi, A., Kalidari, G. A., Hedayati, M. (2010). Isolation and identification of Salmonella Enteritidis and Salmonella Typhimurium from the eggs of retail stores in Mashhad, Iran using conventional culture method and multiplex PCR assay. J Food Safety. 30 (3): 558-568.

10. Fudge, A. M. (2001). Diagnosis and treatment of avian bacterial disease. Semin Avi Exot Pet Med. 10(1): 3-11.

https://doi.org/10.1053/saep.2001.19542

11. Tizard, I. (2004). Salmonellosis in wild birds. Semin Avi Exot Pet Med. 13(2): 50-66. https://doi.org/10.1053/j.saep.2004.01.008

12. Peighambari, S.M., Yazdani, A., Hojjati, P. (2011). Salmonella infection in birds kept in parks and pet shops in Tehran, Iran. Iran J Vet Med. 5(3): 145-148.

13. Chomel, B.B., Belotto, A., Meslin, F. X. (2007). Wildlife, exotic pets, and emerging zoonoses. Emerg Infect Dis. 13 (1): 6. https://doi.org/10.3201/eid1301.060480 PMid:17370509 PMCid:PMC2725831

14. Koochakzadeh, A., Zahraei Salehi, T., Nayeri Fasaei, B., Askari Badouei, M., Oskouizadeh, K. (2015). Detection of Salmonella spp. from some wild captive herbivores in Iran and determination of serogroup, antibiotic susceptibility and presence of invA gene in the isolated strains. Arch Razi Institute 70 (2): 81-87. 
15. Sharifi-Rad, J., Van Belkum, A., Fallah, F., et al. (2016). Rising antimicrobial resistance in Iran. Der Pharm Lett. 8 (7): 31-33.

16. Osmundson, T.W., Eyre, C.A., Hayden, K.M., Dhillon, J., Garbelotto, M.M. (2013). Back to basics: an evaluation of $\mathrm{NaOH}$ and alternative rapid DNA extraction protocols for DNA barcoding, genotyping, and disease diagnostics from fungal and oomycete samples. Mol Ecol Resources. 13 (1): 66-74.

https://doi.org/10.1111/1755-0998.12031

PMid:23121735

17. Zahraei Salehi, T., Tadjbakhsh, H., Atashparvar, N., Nadalian, M., Mahzounieh, M. (2007). Detection and identification of Salmonella Typhimurium in bovine diarrhoeic fecal samples by immunomagnetic separation and multiplex PCR assay. Zoonoses Pub Health. 54 (6-7): 231-236.

https://doi.org/10.1111/j.1863-2378.2007.01061.x PMid:17803511

18. Pan, T.M., Liu, Y.J. (2002). Identification of Salmonella enteritidis isolates by polymerase chain reaction and multiplex polymerase chain reaction. J Microbiol Immunol Infect. 35, 147-151. PMid:12380786

19. Patel, J., Cockerill, III. F., Alder, J., Bradford, P., Eliopoulos, G., Hardy, D., et al. (2014). Performance standards for antimicrobial susceptibility testing; twentyfourth informational supplement. CLSI standards for antimicrobial susceptibility testing 34(1): 1-226.

20. Marchant, P., Hidalgo-Hermoso, E., Espinoza, K., Retamal, P. (2016). Prevalence of Salmonella enterica and Shiga toxin-producing Escherichia coli in zoo animals from Chile. J Vet Sci. 17 (4): 583-586. https://doi.org/10.4142/jvs.2016.17.4.583 PMid:27030195 PMCid:PMC5204038

21. Namroodi, S., Staji, H., Mazandarani, E. (2016). Epidemiological Survey of Salmonella in Rural Cats: A Survey of Serotype, Presence of spv R and spv B Genes, and Antibiotic Resistance Pattern. Iran J Epidemiol. 12 (3): 47-55.

22. Clancy, M.M., Davis, M., Valitutto, M.T., Nelson, K., Sykes, I.V.J.M. (2016). Salmonella infection and carriage in reptiles in a zoological collection. J Am Vet Med Assoc. 248 (9): 1050-1059.

https://doi.org/10.2460/javma.248.9.1050 PMid:27074614

23. Grigar,M.K.,Cummings, K.J., Rodriguez-Rivera,L.D., Rankin, S.C., Johns, K., Hamer, G.L., et al. (2016). Salmonella surveillance among great-tailed grackles (Quiscalus mexicanus) and other urban bird species in Eastern Texas. Vector-Borne Zoonotic Dis. 16 (12): 752-757.

https://doi.org/10.1089/vbz.2016.2000

PMid: 27827557
24. Jang, Y., Lee, S., Lim, J., Lee, H., Kim, T., Park, J., et al. (2008). The rate of Salmonella spp. infection in zoo animals at Seoul Grand Park, Korea. J Vet Sci. 9 (2): 177-181.

https://doi.org/10.4142/jvs.2008.9.2.177

PMid:18487939 PMCid:PMC2839095

25. Friedman, C.R., Torigian, C., Shillam, P.J., Hoffman, R.E., Heltze, D., Beebe, J.L., et al. (1998). An outbreak of salmonellosis among children attending a reptile exhibit at a zoo. J Pediat. 132 (5): 802-807.

https://doi.org/10.1016/S0022-3476(98)70307-5

26. Bender, J.B., Shulman, S.A. (2004). Reports of zoonotic disease outbreaks associated with animal exhibits and availability of recommendations for preventing zoonotic disease transmission from animals to people in such settings. J Am Vet Med Assoc. 224 (7): 1105-1109.

https://doi.org/10.2460/javma.2004.224.1105 PMid:15074855

27. Conrad, C.C., Stanford, K., Narvaez-Bravo, C., Callaway, T., McAllister, T. (2017). Farm fairs and petting zoos: A review of animal contact as a source of zoonotic enteric disease. Foodborne Pathog Dis. 14 (2): 59-73.

https://doi.org/10.1089/fpd.2016.2185

PMid:27992253

28. Uzzau, S.,Brown,D.J., Wallis, T., Rubino, S.,Leori, G., Bernard, S., et al. (2000). Host adapted serotypes of Salmonella enterica. Epidemiol Infect. 125 (2): 229255.

https://doi.org/10.1017/S0950268899004379 PMid:11117946 PMCid:PMC2869595

29. Hernandez, S.M., Keel, K., Sanchez, S., Trees, E., Gerner-Smidt, P., Adams, J.K., et al. (2012). The epidemiology of Salmonella enterica spp. enterica serovar Typhimurium strain associated with a songbird outbreak. Appl Environ Microbiol. 78(20): 7290-7298. PMid: 22885752 PMCid: PMC3457103

30. Crim, S.M., Griffin, P.M., Tauxe, R., Marder, E.P., Gilliss, D., Cronquist, A.B., et al. (2015). Preliminary incidence and trends of infection with pathogens transmitted commonly through food. Foodborne Diseases Active Surveillance Network 10 US sites, 2006-2014. MMWR Morb Mortal Wkly Rep. 64(18), 495-499.

PMid:25974634

31. Hall, A.J., Saito, E.K. (2008). Avian wildlife mortality events due to salmonellosis in the United States, 1985-2004. J Wildlife Dis. 44 (3): 585-593. https://doi.org/10.7589/0090-3558-44.3.585 PMid:18689643 
32. Madadgar, O., Salehi, T.Z., Ghafari, M.M., Tamai, I.A., Madani, S.A., Yahyareyat, R. (2009). Study of an unusual paratyphoid epornitic in canaries (Serinus canaria). Avian Pathology. 38 (6): 437-441. https://doi.org/10.1080/03079450903349170 PMid:19937532

33. Tadesse, D.A., Singh, A., Zhao, S., Bartholomew, M., Womack, N., Ayers, S., et al. (2016). Antimicrobial resistance in Salmonella in the United States from 1948 to 1995. Antimicrob Agent Chemo. 60 (4): 2567-2571.

https://doi.org/10.1128/AAC.02536-15

PMid:26856840 PMCid:PMC4808194

34. Voss-Rech, D., Potter, L., Vaz, C.S.L., Pereira, D.I.B., Sangioni, L.A., Vargas, A.C., et al. (2017). Antimicrobial resistance in nontyphoidal Salmonella isolated from human and poultry-related samples in Brazil: 20-Year meta-analysis. Foodborne Pathog Dis. 14 (2): 116-124.

https://doi.org/10.1089/fpd.2016.2228

PMid:27922763

35. Alley, M., Connolly, J., Fenwick, S., Mackereth, G., Leyland, M., Rogers, L., et al. (2002). An epidemic of salmonellosis caused by Salmonella Typhimurium DT160 in wild birds and humans in New Zealand. New Zealand Vet J. 50 (5): 170-176. https://doi.org/10.1080/00480169.2002.36306 PMid:16032266

36. Handeland, K., Refsum, T., Johansen, B., Holstad, G., Knutsen, G., Solberg, I., et al. (2002). Prevalence of Salmonella Typhimurium infection in Norwegian hedgehog populations associated with two human disease outbreaks. Epidemiol Infect. 128 (3): 523-527. https://doi.org/10.1017/S0950268802007021 PMid:12113498 PMCid:PMC2869850

37. Pires, S.M., Vieira, A.R., Hald, T., Cole, D. (2014). Source attribution of human salmonellosis: an overview of methods and estimates. Foodborne Pathog Dis. 11 (9): 667-676.

https://doi.org/10.1089/fpd.2014.1744

PMid:24885917
38. Dolejska, M., Villa, L., Hasman, H., Hansen, L., Carattoli, A. (2013). Characterization of $\mathrm{IncN}$ plasmids carrying blaCTX-M-1 and qnr genes in Escherichia coli and Salmonella from animals, the environment and humans. J Antimicrob Chemo. 68 (2): 333-339.

https://doi.org/10.1093/jac/dks387

PMid:23060365

39. Mughini-Gras, L., Barrucci, F., Smid, J., Graziani, C., Luzzi, I., Ricci, A., et al. (2014). Attribution of human Salmonella infections to animal and food sources in Italy (2002-2010): adaptations of the Dutch and modified Hald source attribution models. Epidemiol Infect. 142 (5): 1070-1082.

https://doi.org/10.1017/S0950268813001829

PMid:23920400

40. Dunn, J.R., Behravesh, C.B., Angulo, F.J. (2015). Diseases transmitted by domestic livestock: perils of the petting zoo. Microbiology Spectrum 3(6): 227-234.

PMid:27337283

41. Pickering, L.K., Marano, N., Bocchini, J.A., Angulo, F.J. (2008). Exposure to nontraditional pets at home and to animals in public settings: risks to children. Pediatrics 122 (4): 876-886. https://doi.org/10.1542/peds.2008-1942 PMid:18829816

42. Erdozain, G., KuKanich, K., Chapman, B., Powell, D. (2013). Observation of public health risk behaviours, risk communication and hand hygiene at Kansas and Missouri petting zoos-2010-2011. Zoonoses Pub Health. 60 (4): 304-310. https://doi.org/10.1111/j.1863-2378.2012.01531.x PMid:22846186 